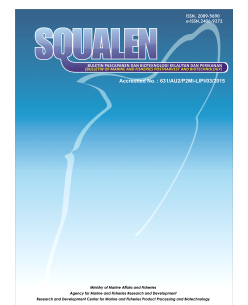

\title{
Health Risk Assessment Related to Total Mercury (THg) Concentration in Clam (Periglypta crispata) from Kepulauan Seribu Regency, Indonesia
}

\author{
Triyoni Purbonegoro ${ }^{*}$ and Suratno ${ }^{2}$ \\ ${ }^{1}$ Research Center for Oceanography, Jl. Pasir Putih 1 Acol Timur, Jakarta, 14430, Indonesia \\ ${ }^{2}$ Research Division for Natural Product Technology, Indonesian Institute of Sciences \\ Jl. Jogja-Wonosari KM 31.5, Gading, Playen, Gunungkidul, Yogyakarta, 55861 Indonesia \\ Article history: \\ Received: 8 January 2020; Revised: 24 March 2020; Accepted: 26 March 2020
}

\begin{abstract}
Mercury $(\mathrm{Hg})$ contaminated seafood can cause severe health problems if it is consumed regularly. Mercury is very dangerous for humans because it can damage or reduce the function of the central nervous system, blood composition, lungs, kidneys, and other vital organs. This metal can also cause birth defects in newly born babies. The objectives of this study were to determine the concentration of total mercury $(\mathrm{THg})$ in clams (Periglypta crispata) collected from Kepulauan Seribu Regency and the safe amount per week for consuming them. The safe amount (kg per week) to consume this clam was calculated by the Maximum Tolerable Intake (MTI) method. Our results showed that the average concentration of $\mathrm{THg}$ in the clams was $0.18 \pm 0.07 \mathrm{mg} / \mathrm{kg}$ wet weight. Among the analyzed organs, $\mathrm{THg}$ accumulation was highest in the digestive tract tissues. The clams were still safe to be consumed by humans since the $\mathrm{THg}$ concentration in these clams has not exceeded the maximum limit of heavy metal in seafood $(0.5 \mathrm{mg} / \mathrm{kg})$ set by the government of Indonesia. The safe amount to consume these clams was $0.53 \mathrm{~kg}$ per week, to avoid the adverse effect of $\mathrm{Hg}$ to human health.
\end{abstract}

Keywords: health risk assessment, mercury, shellfish, Periglypta crispata

\section{Introduction}

Heavy metals such as $\mathrm{Fe}, \mathrm{Cu}$, and $\mathrm{Zn}$ are essential for the metabolism of marine organisms, although at high concentrations they can have adverse effects. Meanwhile, heavy metals such as $\mathrm{Hg}, \mathrm{Pb}$, and $\mathrm{Cd}$ have no known role in biological systems and are toxic even at low concentrations. Mercury $(\mathrm{Hg})$ contamination has become a great concern due to its adverse effects on the ecosystem and human health. This metal is very dangerous for humans because it can damage or reduce the function of the central nervous system, blood composition, lungs, kidneys, and other vital organs. This metal can also cause birth defects in newly born babies (Riani et al., 2018; Selin, 2009). One of the main pathways of $\mathrm{Hg}$ into the human body is through seafood consumption. The most wellknown of $\mathrm{Hg}$ poisoning was the Minamata tragedy in Japan in the 1950s that afflicted fishermen communities who consumed fish and shellfish contaminated with methylmercury $\left(\mathrm{CH}_{3} \mathrm{Hg}\right)$ at high concentration (Selin,
2009). Waste released by the chemical company that polluted the Minamata Bay, including the fish and shellfish populations was suspected to be the cause of this tragedy (Sindermann, 2006). Methylmercury is the predominant (80 to $99 \%$ ) form of total $\mathrm{Hg}(\mathrm{THg})$ in organisms, therefore many studies have been conducted on $\mathrm{THg}$ in the aquatic organisms (Cheng et al., 2009; Liang et al., 2011).

Kepulauan Seribu Regency is part of the Jakarta Province's territorial waters. The area is one of the most important fishery resource areas not only for local people but also for Jakarta's people (Puspaningsih, 2006). Around $71.6 \%$ of the population are fishermen who depend their life on fisheries products (Sachoemar, 2008). However, Kepulauan Seribu Regency is vulnerable to pollution because it is located close to the Jakarta Bay that is well known for contaminated by toxic and hazardous waste because of the increasing development in the Jakarta Province and the surrounding areas (Dwiyitno et al., 2016; Riani et al., 2018; Sachoemar, 2008; Siregar et

${ }^{*}$ Corresponding author.

E-mail: purbonegoro@gmail.com 
al., 2016). The presence of $\mathrm{THg}$ in the Kepulauan Seribu Regency has been confirmed by previous studies. The $\mathrm{THg}$ concentration has been found in the water samples ranged from 0.001 to $0.025 \mathrm{mg} / \mathrm{L}$ (Sachoemar, 2008), in the seagrass (Thalassia hemprichii and Enhalus acoroides) ranged from 7.12 to $87.41 \mu \mathrm{g} / \mathrm{kg}$ dry weight (Suratno \& Irawan, 2018), in the mangrove (Sonneratia alba) ranged 0.0015 to $0.0152 \mathrm{mg} / \mathrm{kg}$ dry weight (Cordova, Dwi, Eftiah, \& Zamani, 2017), and in the fishes ranged from 0.020 to $0.192 \mathrm{mg} / \mathrm{kg}$ dry weight (Puspaningsih, 2006). The THg concentration in the water samples has exceeded the maximum limit of $0.001 \mathrm{mg} / \mathrm{L}(\mathrm{KLH}, 2004)$, whereas the $\mathrm{THg}$ concentration in the fishes was lower than the maximum limit of $0.5 \mathrm{mg} / \mathrm{kg}$ (BPOM, 2018).

Clams are one of the most popular seafood that contain essential amino acids, minerals, vitamins, and unsaturated fatty acids that are important for humans (Fuentes, Fernández-Segovia, Escriche, \& Serra, 2009). This biota is also used to detect environmental pollution due to its life associated with sediment, filter-feeder habits, and its ability to accumulate pollutants (D'costa et al., 2018; Gerhardt, 2002; Zuykov et al., 2013). One of the clam species that is found in Kepulauan Seribu Regency is Periglypta crispata (van der Meij et al., 2009). According to local fishermen, these species are abundant and consumed not only by the local people but also by the residents of Jakarta and the surrounding area. However, our literature review did not found any health risk assessment using $P$. crispata in any location. Therefore, the objectives of this study were to determine the concentration of $\mathrm{THg}$ in clams ( $P$. crispata) obtained from Kepulauan Seribu Regency and the safe amount (kg per week) for consuming them.

\section{Material and Methods}

\subsection{Sample Preparation}

The sampling was conducted in July 2018, to represent East Monsoon (dry season). The samples were obtained from local fishermen who collected the clams by diving at a location between Lancang Besar and Lancang Kecil Island (Figure 1). All samples were cleaned in situ using seawater to remove dirt and fouling organisms. The samples were then put in ziplock plastic bags and stored in a coolbox filled with ice to kept the samples in cold condition $\left( \pm 10^{\circ} \mathrm{C}\right)$ during transportation to the laboratory for analysis. In the laboratory, clam samples were rinsed with deionized water to remove any remaining dirt. A total of 26 clams with relatively similar size were selected to represent the commonly consumed size. The weight and length of each clam were measured by analytical scales (Sartorius, Germany) and Caliper. Clam tissues (siphon, gills, leg muscles, and digestive tract) were then separated using a knife, scissors, and stainless steel tweezers and cut into small pieces. Each part of the tissue was then placed in a petri dish and dried in an oven (Memmert, Germany) for 24 hours at $60^{\circ} \mathrm{C}$

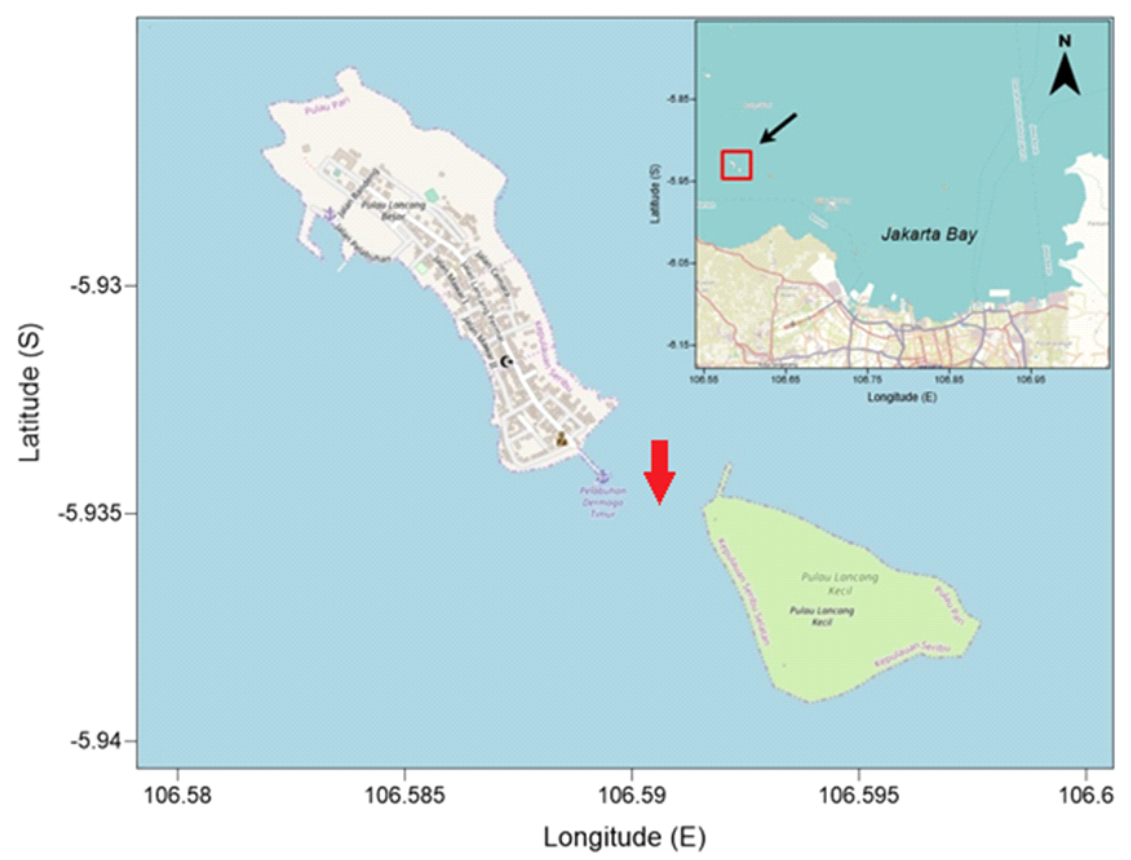

Figure 1. Sampling location at the Lancang Islands (between Lancang Besar Island and Lancang Kecil Island, showed by red arrow), in Kepulauan Seribu Regency 
(SNI No. 01-2354.6-2006). The samples were mashed using a mortar, put in a labeled zip-lock plastic bag, and stored in a desiccator prior to analysis.

\subsection{Measurement of $\mathrm{THg}$ Concentration}

Measurement of $\mathrm{THg}$ in clams was carried out using the Direct Thermal Decomposition Mercury Analyzer NIC MA-3000 (Nippon Instruments Corporation, Japan). This analysis process is based on the USEPA 7473 method Analysis of Mercury in Solids and Solutions by Thermal Decomposition (NIC, 2015). The $\mathrm{Hg}$ standard solutions were prepared with a series of concentration; 0 (blank), 2, 4, 6, 8, 10, 12, $14,16,18$ and $20 \mathrm{ng} / \mathrm{L}$ from a $1000 \mathrm{mg} / \mathrm{L} \mathrm{Hg}$ standard (NIST, Japan). The solutions were stabilized by the addition of L-Cystein solution (NIST, Japan). The LCystein solution was made by dissolving $25 \mathrm{mg}$ of $\mathrm{L}$ Cystein powder with deionized water and addition of $0.5 \mathrm{~mL} \mathrm{HNO}_{3}$ (E. Merck, Germany) in a $250 \mathrm{~mL}$ volumetric flask to reach a concentration of $100 \mathrm{mg} /$ L. Ten to fifteen milligrams of each sample was placed in a ceramic boat and inserted into the furnace of the analyzer. Three replications were made for each sample. DORM 4-Fish Protein Certified Reference Material (National Research Council Canada) was also analyzed to calibrate the instrument. Total mercury concentration in the clam that previously based on dry weight (dw) was converted into wet weight (ww) by using a conversion factor based on the moisture content of the samples. The moisture content ranged from 75.32 to $88.92 \%$ with an average of $80.42 \pm 6.43$ $\%$, hence the conversion factor was 0.19 .

\subsection{Data Analysis and Health Risk Assessment}

Data analysis was performed using Microsoft Excel 2013 and PAST3 (Version 3.25). Since the data were not normally distributed, the significant tests were then performed using the Kruskal-Wallis nonparametric method. The relationship between the size of the clams (based on total weight) and the accumulation of $\mathrm{THg}$ was analyzed using regression linear analysis. Analysis of health risk assessment was carried out by comparing the concentration of $\mathrm{THg}$ in the clam with the maximum limit of $\mathrm{Hg}$ concentration in fishery products set by the government of Indonesia (BPOM, 2018). The safe amount of clam that can be consumed per week without causing health risks was analyzed by calculating Maximum Tolerable Intake (MTI) based on PTWI (Provisional Tolerable Weekly Intake) values. The PTWI value is determined by JECFA (2011) as the basis for determining the Maximum Weekly Intake (MWI). The PTWI is the estimated amount of a substance in food or drink that can be consumed weekly for a lifetime without causing interference or health risks. The PTWI is intended for the intake of contaminants that do not quickly/easily disappear from the human body. The use of the term 'weekly' is intended to emphasize the importance of limiting the frequency of consuming seafood that is suspected of being contaminated not to exceed a certain amount in one week (Herrman \& Younes, 1999).

Previous studies demonstrate that organic $\mathrm{Hg}$ is the predominant $(80$ to $99 \%$ ) form of THg in organisms (Cheng et al., 2009; Liang et al., 2011). Therefore, we use the PTWI for organic $\mathrm{Hg}(1.6 \mu \mathrm{g}$ or $0.0016 \mathrm{mg})$ per kg body weight per week. The bodyweight category is $60 \mathrm{~kg}$ for adults (Ullah, Maksud, Khan, Lutfa, \& Quraishi, 2017; Yap, Cheng, Karami, \& Ismail, 2016). The PTWI based on body weight category or Maximum Weekly Intake (MWI) was calculated using the formula:

$$
\text { MWI = PTWI } \times \text { bodyweight }
$$

Based on the PTWI value, the MWI value for an adult is $0.096 \mathrm{mg} /$ week. The Maximum Tolerable Intake (MTI) was calculated using the formula according to Azhar et al. (2012) and Afandi et al. (2019):

$$
M T I=\frac{M W I}{M C}
$$

Where, $\mathrm{Mc}$ is the total concentration of $\mathrm{THg}$ in the clam ( $\mathrm{mg} / \mathrm{kg}$ wet weight). This value is the sum of the concentration in the siphon, gills, foot, and digestive tract.

\section{Results and Discussion}

\subsection{THg Concentration in Clam}

The average concentration of $\mathrm{THg}$ in the clams $P$. crispata collected from Kepulauan Seribu Regency (Lancang Islands) was $0.18 \pm 0.07 \mathrm{mg} / \mathrm{kg}$. The average concentration of $\mathrm{THg}$ in each part of the body was $0.04 \pm 0.01 \mathrm{mg} / \mathrm{kg}$ in the siphon, $0.04 \pm 0.01 \mathrm{mg} / \mathrm{kg}$ in the gills, $0.04 \pm 0.01 \mathrm{mg} / \mathrm{kg}$ in the foot, and $0.07 \pm 0.04$ $\mathrm{mg} / \mathrm{kg}$ in the digestive tract (Figure 2). There was no significant difference between $\mathrm{THg}$ concentrations in the siphon, gills, and foot. In the contrary, the concentration of $\mathrm{THg}$ in the digestive tract was significantly higher than the other organs. The size (weight) of the clams were varied greatly. The size ranged between 43 to $230 \mathrm{~g}$ with an average of $129 \pm 46.6 \mathrm{~g}$. However, the result of linear regression analysis showed no significant relationship between the concentration of $\mathrm{THg}$ and the size (weight) of the clams $\left(R^{2}=0.024\right)$. Our results also showed that the THg concentration in the clams $P$. crispata has not exceeded the maximum limit of heavy metal in seafood $(0.5 \mathrm{mg} / \mathrm{kg})$ set by the government of Indonesia (BPOM, 2018). 


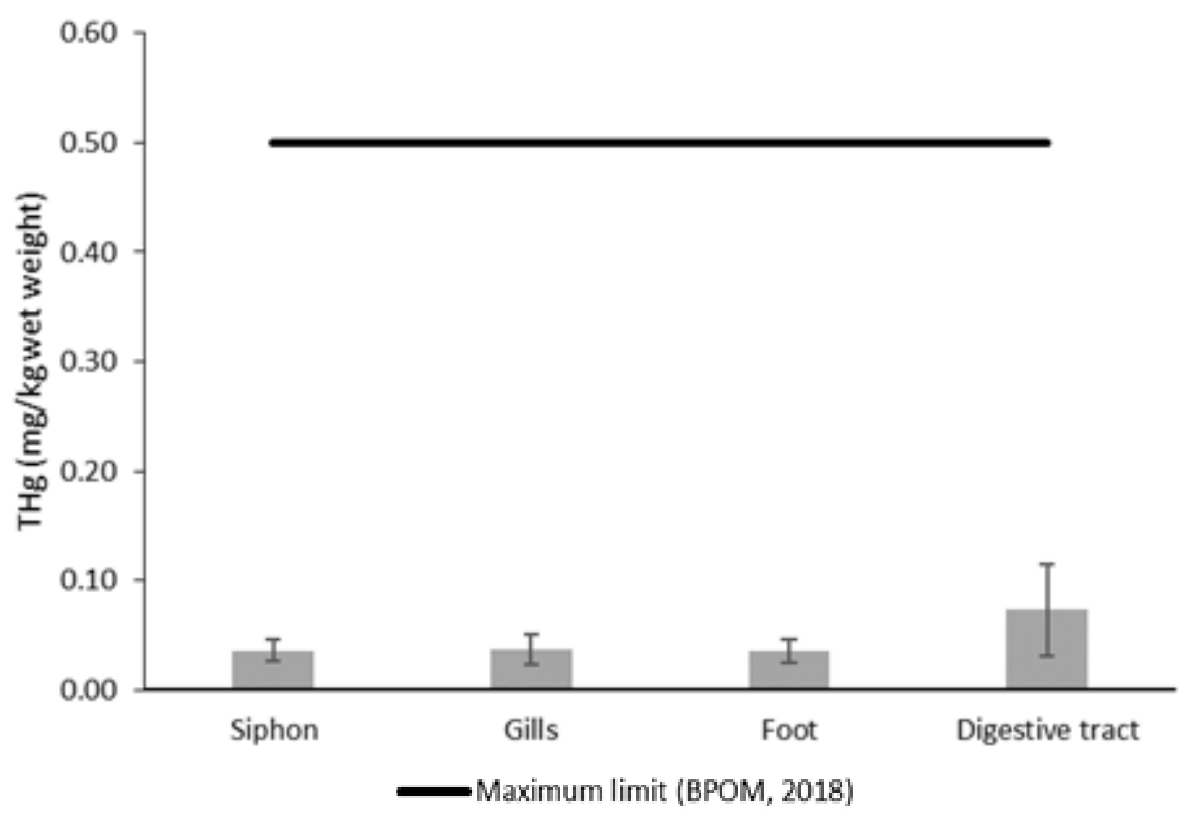

Figure 2. The average concentration of total $\mathrm{Hg}(\mathrm{mg} / \mathrm{kg}$ wet weight) in the clam Periglypta crispata from Lancang Islands, Kepulauan Seribu Regency

Our literature review did not found any studies related to heavy metals contamination in $P$. crispata. Therefore, our result is compared with the studies that have reported the $\mathrm{Hg}$ contamination in other clams species in several Indonesian coastal areas (Table 1). According to Table 1 , the potential of each species to accumulate $\mathrm{THg}$ is relatively different. The concentration of $\mathrm{THg}$ in the present study is higher than those in the Meretrix meretrix from Banjarmasin, Marcia hiantina from Makassar, Anadara antiquata from Bintan, Paphia undulata from Surabaya and Demak, and $A$. antiquata from Surabaya. However, they are lower than those in the Polymesoda erosa from the Buru Regency, and $A$. granosa and $A$. inaequivalvis from Surabaya and Demak.

Potential sources of $\mathrm{Hg}$ in the Lancang Islands as the study site were previously reported by several studies. Sachoemar (2008) explained that Lancang Islands, together with Untung Jawa Island and Pari Island, are directly close to Jakarta Bay. Therefore those islands are vulnerable to pollution that comes from Jakarta Bay. The $\mathrm{Hg}$ concentration in the seawater of Lancang Islands was ranged between 0.041 to $32.46 \mu \mathrm{g} / \mathrm{L}$ (Puspaningsih, 2006; Sachoemar, 2008). Meanwhile, the average of $\mathrm{THg}$ concentration in the sediment of Lancang Islands was $22.43 \pm 5.59$ $\mu \mathrm{g} / \mathrm{kg}$ (Suratno \& Irawan, 2018). The life of clams that associated with sediment and their filter-feeder habits, makes them potential to accumulate pollutants from the environment (Zuykov et al., 2013; Gerhardt 2002; D'costa et al., 2018).
In the present study, the highest concentration of $\mathrm{THg}$ was found in the digestive tract of the clams. The tendency of $\mathrm{Hg}$ to accumulate in the digestive tract and glands of bivalve was also confirmed by Raftopoulou and Dimitriadis (2011). Marigómez et al. (2002) explained that the digestive gland of a bivalve is a target organ for metal bioaccumulation and detoxification. The effective detoxification mechanisms in the digestive tract were involving the increasing level of metallothioneins and the glutathione as metal ligands (Raftopoulou \& Dimitriadis, 2011).

No significant relationship between the concentration of $\mathrm{THg}$ and the size of the clams was also confirmed by previous studies. Mallongi (2014) found the THg concentration in the clam M. hiantina from Makassar City was not significantly different between small-sized (ranged from 0.5 to $2.5 \mathrm{~g}$ ) and large-sized clams (ranged from 3.1 to $10 \mathrm{~g}$ ). The THg concentration ranged from 0.042 to $0.112 \mathrm{mg} / \mathrm{kg}$ in small-sized clams and 0.044 to $0.077 \mathrm{mg} / \mathrm{kg}$ in the large-sized clam. This indicates that the increasing size of the clams does not always follow by the higher concentration of THg. Hédouin et al. (2006) explained that in bivalves, metal concentrations in the body may either decrease, increase or remain constant with increasing body size, depending on the metal and the species. In addition, some biological processes such as metabolic rates are likely to take part in the observed relationships as well. The metabolic rate decreases with age and metal behavior in the organism 
varies according to the different life stages (Hédouin et al., 2006).

\subsection{Health Risk Assessment}

Based on the average $\mathrm{THg}$ concentration in the clams $(0.18 \mathrm{mg} / \mathrm{kg})$, the amount of clams that allowed to be consumed by a $60-\mathrm{kg}$ adult to reach JECFA limits was $0.53 \mathrm{~kg}$ per week. In other words, if a batch of clams has a THg concentration of $0.18 \mathrm{mg} / \mathrm{kg}$, a maximum amount of clams that allowed to be consumed by a $60-\mathrm{kg}$ adult is $0.53 \mathrm{~kg}$ per week. The MTI value in the present study (Table 1) is lower than those for consuming clams $M$. meretrix from Banjarmasin, M. hiantinafrom Makassar, P. erosa and $A$. antiquata from Bintan, $P$. undulata from Surabaya and Demak, and $A$. antiquata from Surabaya. However, they are higher than MTI value for consuming clams $P$. erosa from the Buru Regency, and $A$. granosa and $A$. inaequivalvis from Surabaya and Demak.

Those studies revealed that the MTI value depends on the species of clams being consumed and the accumulation of $\mathrm{THg}$ in the body of the clams. Therefore, high concentrations of $\mathrm{THg}$ have consequences for limiting the number of clams that can be consumed in a week. The MTI values will vary spatially and temporally, depending on the available data. Thapa et al. (2014) suggest that the government should be responsible for obtaining information on the available data and contaminant levels for commonly eaten clams species. Therefore, it will allow people to make good decisions about the health risks from clams consumption.

In addition, the efforts to reduce the intake of $\mathrm{Hg}$ into the human body can also be done by reducing the concentration of $\mathrm{Hg}$ in clams before consumption. These efforts can be done by using absorbent media, such as chitosan solution made from shrimp head waste. Murtini et al. (2004) proved that the use of a $1.5 \%$ chitosan solution for 3 hours can reduce the $\mathrm{Hg}$ concentration in green mussels by $94.89 \%$. The use of a $1.5 \%$ chitosan solution for 3 hours can also reduce the $\mathrm{Pb}$ concentration up to $96.48 \%$. As our results showed that the highest concentration of $\mathrm{THg}$

Table 1. The concentration of THg in the clam species in several Indonesian coastal areas and the recommended MTI value for consuming the clams

\begin{tabular}{|c|c|c|c|}
\hline Clam species (location) & $\begin{array}{c}\text { THg conc. } \\
\text { (mg/kg wet weight) }\end{array}$ & $\begin{array}{c}\text { MTI } \\
\text { (kg per week) }\end{array}$ & References \\
\hline $\begin{array}{l}\text { Periglypta crispata } \\
\text { (Kepulauan Seribu Regency, Jakarta) }\end{array}$ & 0.18 & 0.53 & Present study \\
\hline $\begin{array}{l}\text { Meretrix meretrix } \\
\text { (Banjarmasin, South Kalimantan) }\end{array}$ & 0.001 & 96 & $\begin{array}{l}\text { Murtini and Peranginangin } \\
\text { (2006) }\end{array}$ \\
\hline $\begin{array}{l}\text { Marcia hiantina } \\
\text { (Losari coastal area, Makassar South } \\
\text { Sulawesi) }\end{array}$ & $0.04-0.11$ & 1.6 & Mallongi (2014) \\
\hline $\begin{array}{l}\text { Polymesoda erosa } \\
\text { (Buru Regency, Maluku) }\end{array}$ & 0.756 & 0.127 & Eka et al. (2019) \\
\hline Polymesoda erosa (Bintan, Riau) & $0.03-0.26$ & 3.22 & Budiyanto et al. (2019) \\
\hline Anadara antiquata (Bintan, Riau) & $0.04-0.09$ & 4.18 & Budiyanto et al. (2019) \\
\hline $\begin{array}{l}\text { Anadara granosa } \\
\text { (Surabaya and Demak) }\end{array}$ & 0.31 & 0.31 & Suryono et al. (2019) \\
\hline $\begin{array}{l}\text { Anadara inaequivalvis } \\
\text { (Surabaya and Demak) }\end{array}$ & 0.58 & 0.17 & Suryono et al. (2019) \\
\hline $\begin{array}{l}\text { Paphia undulata } \\
\text { (Surabaya and Demak) }\end{array}$ & 0.09 & 1.07 & Suryono et al. (2019) \\
\hline $\begin{array}{l}\text { Anadara antiquata } \\
\text { (Surabaya, East Java) }\end{array}$ & 0.08 & 4.49 & Purnadayanti et al. (2019) \\
\hline
\end{tabular}


was found in the digestive tract, it is strongly recommended to dispose of this part of the clam's body prior to consuming.

\section{Conclusion}

The average concentration of THg in the clams $P$. crispata collected from Kepulauan Seribu Regency (Lancang Islands) was $0.18 \pm 0.07 \mathrm{mg} / \mathrm{kg}$ wet weight. The average concentration of $\mathrm{THg}$ in the digestive tract was significantly higher than the other organs (siphon, gills, and foot). The clams were still safe to be consumed by humans since the $\mathrm{THg}$ concentration in these clams has not exceeded the maximum limit of heavy metal in seafood $(0.5 \mathrm{mg} / \mathrm{kg})$ set by the government of Indonesia. The safe amount to consume these clams was $0.53 \mathrm{~kg}$ per week, to avoid the adverse effect of $\mathrm{Hg}$ on human health. Although the $\mathrm{THg}$ concentration is still below the maximum limit, more attention must be given to the consumption of clams by susceptible groups such as children and pregnant women.

\section{Acknowledgment}

The authors thanks Kus Mutia Noventi Wibowo for her help in this study. This study was funded by the Demand Driven Research Grant, Coremap-CTI Indonesian Institute of Sciences (LIPI) Fiscal Year 2018 (No. B-1191 / IPK 2 / KS.02 / III / 2018).

\section{References}

Afandi, M. F., Widowati, I., \& Ambariyanto, A. (2019). Zinc content in water, sediment, and soft tissue of green mussel Perna viridis in Demak, Indonesia. $A A C L$ Bioflux, 12(1), 201-208.

Azhar, H., Widowati, I., \& Suprijanto, J. (2012). Studi Kandungan logam berat $\mathrm{Pb}, \mathrm{Cu}, \mathrm{Cd}$, Cr pada kerang simping (Amusium pleuronectes), air dan sedimen di Perairan Wedung, Demak serta analisis maximum tolerable intake pada manusia. Journal of Marine Research, 1(2), 35-44.

BPOM. (2018). Peraturan Badan Pengawas Obat dan Makanan Nomor 5 tentang Batas Maksimum Cemaran Logam Berat Dalam Pangan Olahan. In Badan Pengawas Obat dan Makanan Republik Indonesia. Badan Pengawas Obat dan Makanan Republik Indonesia.

Budiyanto, F., Arbi, U. Y., \& Suratno. (2019). Risk assessment on mercury concentration in six edible mollusks from Bintan Island, Indonesia. AIP Conference Proceedings, 2120(July). https://doi.org/ 10.1063/1.5115647

Cheng, J., Gao, L., Zhao, W., Liu, X., Sakamoto, M., \& Wang, W. (2009). Mercury levels in fisherman and their household members in Zhoushan, China: impact of public health. Science of the Total Environment, 407, 2625-2630.

Cordova, M. R., Dwi, F., Eftiah, M., \& Zamani, N. P. (2017). Ability of mangrove apple as mercury bioindicator. Omni-Akuatika, 13(2), 137-143.

D'costa, A. H., Shyama, S. K., Praveen, P. K., \& Furtado, S. (2018). The Backwater Clam (Meretrix casta) as a bioindicator species for monitoring the pollution of an estuarine environment by genotoxic agents. Mutation Research-Genetic Toxicology and Environmental Mutagenesis, 825(November 2017), 8-14. https://doi.org/10.1016/j.mrgentox.2017.11.001

Dwiyitno, Dsikowitzky, L., Nordhaus, I., Andarwulan, N., Irianto, H. E., Lioe, H. N., ... Schwarzbauer, J. (2016). Accumulation patterns of lipophilic organic contaminants in surface sediments and in economic important mussel and fish species from Jakarta Bay, Indonesia. Marine Pollution Bulletin, 110(2), 767-777. https://doi.org/10.1016/j.marpolbul.2016.01.034

Eka, R., Rohim, T., Bacrudin, L., Pudji, R., Syamsiar, R., Atjo, W., \& Ahsan, M. A. (2019). Determining mercury safe concentration in shells in the unlicensed gold mining area of Kayeli Village, Buru Regency, Maluku Province, Indonesia. Indian Journal of Public Health Research \& Development, 10, 1230-1234.

Fuentes, A., Fernández-Segovia, I., Escriche, I., \& Serra, J. A. (2009). Comparison of physico-chemical parameters and composition of mussels (Mytilus galloprovincialis $L m k$.) from different Spanish origins. Food Chemistry, 112(2), 295-302. https://doi.org/ 10.1016/j.foodchem.2008.05.064

Gerhardt, A. (2002). Bioindicator species and their use in bio-monitoring. In I. $\mathrm{HI} \& \mathrm{D}$. JL (Eds.), Environmental Monitoring. Encyclopedia of Life Support Systems (EOLSS), Oxford.

Hédouin, L., Metian, M., Teyssié, J. L., Fowler, S. W., Fichez, R., \& Warnau, M. (2006). Allometric relationships in the bioconcentration of heavy metals by the edible tropical clam Gafrarium tumidum. Science of the Total Environment, 366(1), 154-163. https://doi.org/10.1016/j.scitotenv.2005.10.022

Herrman, J. L., \& Younes, M. (1999). Background to the ADI/TDI/PTWI. Regulatory Toxicology and Pharmacology, 30(2 II), 109-113. https://doi.org/10. 1006/rtph.1999.1335

JECFA. (2011). Mercury. In Safety evaluation of certain contaminants in food-Mercury. WHO food additives series (pp. 605-684). Retrieved from http:// www.fao.org/3/a-at881e.pdf

KLH. (2004). Keputusan Menteri Negara Lingkungan Hidup Nomor 51 Tahun 2004. Lampiran III Tentang Baku Mutu Air Laut Untuk Biota Laut. In Keputusan Menteri Negara Lingkungan Hidup Nomor 51 Tahun 2004 Tentang Baku Mutu Air Laut (p. 4). Kementerian Lingkungan Hidup Republik Indonesia.

Liang, P., Shao, D. D., Wu, S. C., Shi, J. B., Sun, X. lin, Wu, F. Y., ... Wong, M. H. (2011). The influence of mariculture on mercury distribution in sediments and fish around Hong Kong and adjacent mainland China 
waters. Chemosphere, 82(7), 1038-1043. https:// doi.org/10.1016/j.chemosphere.2010.10.061

Mallongi, A. (2014). Environmental Risks of Mercury Contamination in Losari Coastal Area of Makassar City, Indonesia. International Journal of Scientific and Research Publications, 4(2), 2-7. Retrieved from www.ijsrp.org

Marigómez, I., Soto, M., Cajaraville, M. P., Angulo, E., \& Giamberini, L. (2002). Cellular and subcellular distribution of metals in molluscs. Microscopy Research and Technique, 56(5), 358-392.

Murtini, J. T., Januar, H. I., \& Sugiyono. (2004). Upaya pengurangan cemaran logam berat pada daging Kerang Hijau (Perna viridis) dengan larutan kitosan. Jurnal Penelitian Perikanan Indonesia, 10, 1-4.

Murtini, J. T., \& Peranginangin, R. (2006). Full Paper. Jurnal Perikanan, VIII(2), 177-184. https://doi.org/ 10.33369/pendipa.v1i1.2982

NIC. (2015). Fully-automatic Thermal Vaporization Mercury Analysis System Mercury/MA- 3000 Instruction Manual. Osaka: Nippon Instruments Corporation.

Purnadayanti, Z., Suratno, S., Iranawati, F., \& Purbonegoro, T. (2019). Food Safety Level on Bivalves Consumption from Kenjeran Waters Surabaya, East Java. IOP Conference Series: Materials Science and Engineering, 546(2). https://doi.org/10.1088/1757899X/546/2/022016

Puspaningsih, D. (2006). Analisa kandungan logam berat $\mathrm{Hg}$ di sekitar perairan Kepulauan Seribu. Prosiding Seminar Nasional Tahunan III. Hasil Penelitian Perikanan dan Kelautan, Yogyakarta 27 Juli 2006. Universitas Gadjah Mada.

Raftopoulou, E. K., \& Dimitriadis, V. K. (2011). Comparative study of the accumulation and detoxification of $\mathrm{Cu}$ (essential metal) and $\mathrm{Hg}$ (nonessential metal) in the digestive gland and gills of mussels Mytilus galloprovincialis, using analytical and histochemical techniques. Chemosphere, 83(8), 1155-1165. j.chemosphere.2011.01.003

Riani, E., Cordova, M. R., \& Arifin, Z. (2018). Heavy metal pollution and its relation to the malformation of green mussels cultured in Muara Kamal waters, Jakarta Bay, Indonesia. Marine Pollution Bulletin, 133(January 2017), 664-670. https://doi.org/10.1016/ j.marpolbul.2018.06.029

Sachoemar, S. I. (2008). Karakteristik Lingkungan Perairan Kepulauan Seribu. Jurnal Air Indonesia, $4(2), 109-114$.

Selin, N. E. (2009). Global Biogeochemical Cycling of Mercury: A Review. Annual Review of Environment and Resources, 34(1), 43-63. https://doi.org/10.1146/ annurev.environ.051308.084314

Sindermann, C. J. (2006). Coastal pollution: effects on living resources and humans. Boca Raton, Florida: CRC Press.

Siregar, T. H., Priyanto, N., Putri, A. K., Rachmawati, N., Triwibowo, R., Dsikowitzky, L., \& Schwarzbauer, J. (2016). Spatial distribution and seasonal variation of the trace hazardous element contamination in Jakarta Bay, Indonesia. Marine Pollution Bulletin, 110(2), 634-646. https://doi.org/10.1016/ j.marpolbul.2016.05.008

Suratno \& Irawan, A. (2018). Mercury concentration on Enhalus acoroides and Thalassia hemprichii at Seribu Islands. IOP Conference Series: Earth and Environmental Science, 3-8. IOP Publishing.

Suryono, C. A., Sabdono, A., \& Subagiyo, S. (2019). Bioakumulasi Arsen (As) dan Merkuri ( $\mathrm{Hg}$ ) pada Bivalvia dari Pesisir Sekitar Demak dan Surabaya Indonesia. Jurnal Kelautan Tropis, 22(2), 157-164. https://doi.org/10.14710/jkt.v22i2.6257

Thapa, D. S., Sharma, C. M., Kang, S., \& Sillanpää, M. (2014). The Risk of Mercury Exposure to the People Consuming Fish from Lake Phewa, Nepal. International Journal of Environmental Research and Public Health, 11, 6771-6779. https://doi.org/ 10.3390/ijerph110706771

Ullah, A. K. M. A., Maksud, M. A., Khan, S. R., Lutfa, L. N., \& Quraishi, S. B. (2017). Dietary intake of heavy metals from eight highly consumed species of cultured fish and possible human health risk implications in Bangladesh. Toxicology Reports, 4(July), 574-579. https://doi.org/10.1016/ j.toxrep.2017.10.002

van der Meij, S. E. T., Moolenbeek, R. G., \& Hoeksema, B. W. (2009). Decline of the Jakarta Bay molluscan fauna linked to human impact. Marine Pollution Bulletin, 59(4-7), 101-107. https://doi.org/10.1016/ j.marpolbul.2009.02.021

Yap, C. K., Cheng, W. H., Karami, A., \& Ismail, A. (2016). Health risk assessments of heavy metal exposure via consumption of marine mussels collected from anthropogenic sites. Science of the Total Environment, 553, 285-296. https://doi.org/10.1016/ j.scitotenv.2016.02.092

Zuykov, M., Pelletier, E., \& Harper, D. A. T. (2013). Bivalve mollusks in metal pollution studies: From bioaccumulation to biomonitoring. Chemosphere, 93(2), 201-208. https://doi.org/10.1016/ j.chemosphere.2013.05.001 